\title{
INCOME SMOOTHING AND MARKET PERCEPTION OF ACCOUNTING NUMBERS: AN EMPIRICAL INVESTIGATION OF EXTRAORDINARY ITEMS
}

\author{
Wan Adibah Wan Ismail, Khairul Anuar Kamarudin \\ and Muhd Kamil Ibrahim
}

\section{SIRACT}

antilaysian companies. The first issue concerns the change of accounting standards on extraordinary was which has limited the scope of extraordinary items. It is found that there are significant zinges on the incidence of reported extraordinary items during the period after the adoption of a a sex standard. The findings supported the arguments that the new standard on extraordinary consequently reduce significantly the items from financial statements. This paper esizes that extraordinary items classification choice is a means used by companies to smooth Two types of statistical tests performed have confirmed the proposition that the disclosure ordinary items is subject to this type of manipulation during the period before the adoption te new standard. Although it is proved that the broad definition of extraordinary items allows tanies to manipulate income, evidence gathered from multivariate regressions demonstrate extraordinary items are value-relevance for investors in valuing a firm's equity. Thus, investors into account the extraordinary items even though it is disclosed 'below the line'.

\section{INTRODUCTION}

Financial statements are prepared in order to communicate economic measurements and information about the resources and performance of a reporting entity. One could argue that the purposes of financial statements are to provide information about the financial position, performance and cash flow of an enterprise and to show the results of management's stewardship of the resources encrusted to it, for the use of a wide range of users in making economic decisions. Since the users

This study was made possible by the research grant provided by MARA University of Technology and we are thankful af the university for its research support. This paper has benefited from valuable comments of Stuart Mccleay, Juhari Samidi and seminar participants of INSIGHT 2002, Kuala Lumpur (24-25 August 2002) and 1st International Conference an Business \& Economics at Kota Kinabalu, Sabah, 10-12 July 2003. Valuable comments from anonymous referees are gratefully acknowledged. 
of financial statements have no access to a company's accounting records, they depend greatly on the financial statements when making judgments and decisions. However, the increasing trend of creative accounting has made the financial statements less reliable and less transparent. Accountants prepare the statements to "window-dress" their organizations by taking advantage of the loopholes in accounting standards. Although creative accounting is not against the law, in the hands of less scrupulous management, it can be a highly dangerous instrument of deception (Naser, 1993). The investing community at large can be misled into making decisions from information which is based on manipulated accounting figures. To a certain extent, the existence of creative accounting distorts the usefulness of financial statements and impedes them from meeting the prescribed objectives.

This research examines one component in financial statements that is very commonly subjected to creative accounting that is the extraordinary items. The International Accounting Standard (IAS) 8 issued by the International Accounting Standard Committee (IASC) in 1978 has broadly defined extraordinary items as

"...gains or losses that derive from events or transactions that are distinct from the ordinary activities of the enterprise and therefore no expected to recur frequently or regularly" (Para. 3).

This standard was adopted in Malaysia as Standard International 8 (SI 8). It is argued that as a result of this broad definition of extraordinary items, companies have considerable discretion in classifying items as "extraordinary" or part of ordinary operations. A company may use the category of extraordinary items to report costs to be excluded from the company's pretax income, and more importantly, from its earnings per share record (Naser, 1993). This is because an earnings per share is the main component in the price earnings ratio, which is used by the stock market as a key performance indicator. Other than the price earnings ratio, financial ratios such as return on equity (ROI) and return on asset (ROA) that are widely used by investors also depend on the net profit after tax, which excludes extraordinary items. As discussed by Choo and Peter (1998), investors tend to fixate on net profit after tax (the bottom line) and pay little or no attention to extraordinary items although the latter form part of the enterprise's performance for the period.

The manipulation of extraordinary items in the income statements has some impact on the company's shareholders. It is common that investors use the reported income for a particular accounting period to assess the current performance of the enterprise and to form or revise their expectations of the income of the enterprise in the future (Choo and Peter, 1998). With the manipulation, these investors can be misled into making decisions from information, which 
= fill nor fair. Therefore, what constitutes as extraordinary items is an important question wan analid be taken seriously by the accounting professionals.

Tha anercome the problem of creative accounting particularly the abuse of extraordinary items an wancil statements, accounting standard setting bodies have taken steps to revise the accounting animusits on the reporting of extraordinary items by redefining what constitutes extraordinary un Most standard setting bodies provide a narrow definition of the items. According to Abdullah ani Ir lamail (2000), the adoption of the revised standard was expected to curb the abuse in the anaming of extraordinary items. A study by Naser (1993), recommended that a stricter accounting ann was the most agreed solution to eliminate the use of creative accounting.

14 1992, the IASC amended the International Accounting Standard (IAS) 8 and issued a revised g standard on extraordinary items IAS 8 (Revised), Net Profit or Loss for the Period, Error and Changes in Accounting Policies, which covered the reporting of extraordinary ong other things. Under the revised standard, extraordinary items were defined as income or expenses that arise from events or transactions that are clearly distinct fum the ordinary activities of the enterprise and therefore not expected to recur frequently ar regularly".

The =ord "clearly" was added to reduce the degree of generality in the original definition of inary items. In a step further, the term "ordinary activities" was defined as

_ activities which are undertaken by an enterprise as part of its business and such related activities in which the enterprise engages in furtherance of, incidental to, or arising from clearly those activities."

In addition to this, Paragraph 12 of IAS 8 (Revised) states, "only on rare occasions does an enent or transaction give rise to an extraordinary item". In Paragraph 14, the IAS 8 (Revised) ffectively limits extraordinary items into expropriation of assets and natural disasters. Other enents, such as litigation settlements and disposals of plant, property and equipment, which used a be classified as extraordinary items, are now re-classified as abnormal or exceptional items, which form part of the operating profit figure. According to Choo and Peter (1998), the restricted deffition of extraordinary items in IAS 8 (Revised) has effectively abolished extraordinary items from the income statement.

In Malaysia, the IASC's revised standard on extraordinary items, IAS 8 (Revișed) was adopted in 1997 as SI 8 (Revised) to replace the existing standard on the treatment of extraordinary items 
in financial statements, the SI 8. Subsequently, in 1999 the SI 8 (Revised) was adopted by the Malaysian Accounting Standard Board (MASB) and known as MASB standard no.3 (MASB 3). Both the SI 8 (Revised) and MASB 3 were made effective for financial statements commencing on or after 1st January 1997 and 1st July 1999 respectively. Basically, there is no significant difference between the SI 8 (Revised) and MASB 3 since most of the content in MASB 3 is merely an adoption of IAS 8 (Revised).

MASB 3 states, "extraordinary items arise from an event that possesses a high degree of abnormality that is clearly distinct from the ordinary activities of the enterprise and not expected to recur in the foreseeable future". For example, losses sustained as a result of a typhoon would normally qualify as an extraordinary item unless it is of a scale that could be considered a natural disaster In addition, the standard also specifies certain items that are normally accounted for as extraordinary items under IAS 8, such as a litigation settlement and the disposal of land to be accounted for as 'exceptional' items and included in the determination of net income (Para 16 and 18).

Based on these background, the first issue in this study is to empirically examine whether the introduction and the adoption of the newly revised standards on extraordinary items in Malaysiz really has significantly changed the way of reporting these items in the financial statements. In other words, are there any changes or reduction in the number of incidence of the reported extraordinary items before and after the adoption of the new standard, SI 8 (revised)? If there no change in the reporting of extraordinary items, there may be a possibility that the new standar: is still not being put into practice by Malaysian companies, as has happened in Hong Kong (Lynt and McGuinness, 1995) and Singapore (Choo and Peter, 1998).

Lynn and McGuinness (1995) reported that there was a rather "liberal" usage of extraordinar items in Hong Kong even after the adoption of the new revised standard, which had simila recommendations to that of SI 8 (revised). The study concluded that in Hong Kong, many companie did not welcome the implementation of the restricted usage of extraordinary items. Some firms responses to the new standard were so adverse that even the threat of audit qualifications coul not convince them to comply with the re-defined extraordinary items rules. From their researck it is apparent that the introduction of the new accounting standard in Hong Kong was not effective

Similarly, Choo and Peter (1998) reported that in Singapore, the adoption of Provisional Stateme of Accounting Standard (PAS) 19 in 1994 to restrict the usage of extraordinary items was n effective. The restricted definition of extraordinary items in the standard had been met wi considerable objection from the business community. As a result, the accounting standard setti body in Singapore withdrew the standard in 1995. 
tratifition to the above issue, this research also focuses on determining whether extraordinary we is being used as a tool in income smoothing. Previous literatures provide evidence that items have been used as a device to smooth a company's reported income. In the Barnea et al. (1976) confirmed that extraordinary items were used in classificatory They suggested management classified items, which potentially could be labelled as to dampen the fluctuation of income before extraordinary items over time. This ported by Craig and Walsh (1989), who examined the practice of reporting extraordinary wn in Australian listed companies. Craig and Walsh (1989) concluded, "there is evidence that man classes of larger companies have used material extraordinary items adjustments to indulge twannipulative, profit smoothing, creative accounting practices."

Further evidence of using extraordinary items as a smoothing instrument was provided in a British companies by Beattie et. al (1994). The study found that smoothing behaviour tively associated with earnings variability and when managers of companies have share Conversely, studies conducted in Hong Kong and Singapore provided different results. and McGuinness (1995) and Choo and Peter (1998) found that extraordinary items were not sed as an instrument in income smoothing in Hong Kong and Singapore respectively.

tyurt from that, this study extends further to answer the question of whether the issue surrounding Ginary items is really important for the investors, or whether the flexibility and choices of ing method just create 'noise' in the security market. One of the possibilities is to examine er the market perceives extraordinary items as an important variable in the determination a company's value. In other words, this study investigates whether the extraordinary items ed in income statements have been taken into consideration by investors when valuing the price of the firms.

\section{THEORETICAL FRAMEWORK}

The positive accounting theory assumes that agents are rational individuals who are concern with furthering their own self-interest. Consistent with this, it is assumed that the motivating fictor influencing managers' action is the maximization of their utility. In other words, managers will take action that will consequently increase their salaries, bonuses and other benefits. By smoothing income levels, managers can generate a less volatile reported income pattern, compared we the real income pattern. With the lower volatility of income, market's perception of default risk will be lower. The low perceived default risk would consequently increase the firm's value and improve the assessment of managers' performance. The empirical evidences proved that share grices are influenced by a company's reported profit in relation to market expectations, (Cornell 
and Landsman, 1989). Managers would be concerned if the reported profits are less than the market expectation because lower reported profit would result in lower share prices (e.g. Ball and Brown, 1969). In this situation, the managers would be motivated to manipulate reported profits to bring them closer to market expectations. Thus, there is a possibility that managers may engage in income smoothing practices in order to satisfy the shareholders, which in turn increases the firm's value. This can be done by manipulating certain accounting items that are subject to their discretion.

\section{HYPOTHESES DEVELOPMENT}

This section focuses on the development of three hypotheses that are used in this study. The areas of interest revolve around the issues of extraordinary items, including the effects of the adoption of new standards on extraordinary items, the usage of extraordinary items in income smoothing and market perception towards extraordinary items in valuing a firm's equity.

\section{Hypothesis 1}

The implementation of new accounting standards is one of the means to overcome the income smoothing practice. According to Naser (1993), the existence of a classificatory choice in accounting practice creates a loophole, which allows the companies to manipulate accounting numbers, particularly the reported earnings. Therefore, the adoption of the new standards may reduce the manipulation of extraordinary items in smoothing the profit (Abdullah and Ku Ismail, 2000).

Apart from this, it is important to review the changes in reported extraordinary items, before and after the adoption of the new standards. Any significant change in the reported extraordinary items of these two periods will give signal that may support further analysis of extraordinary items usage in income smoothing. To test whether there is a significant difference between the reported extraordinary items before and after the adoption of the new standards, the following hypothesis has been developed:

$\mathrm{H}_{1}$ : There is a significant difference between the incidence of extraordinary items during the period before and after the adoption of the new standards among Malaysian listed companies.

\section{Hypothesis 2}

This hypothesis focuses on income smoothing. The possibility that smoothing occurs is baset on the premise that management tries to smooth reported earnings to maximize their self-interest 
, 1998). By smoothing income levels, managers can generate a less volatile reported compared to the real earning pattern. With the lower volatility of earnings, the eption of default risk will be lower. The low perceived default risk would consequently firm's value and improve the assessment of managers' performance. Other than managers, s also prefer a smoothed income if the firm's value is assessed higher. Moreover, a a smooth income stream is usually considered as having greater growth potential, which tigher share prices. Thus, Choo and Peter (1998) argue that shareholders would have s to disregard the income smoothing behaviour of managers, and favour the choice of ' accounting practice that permits such behaviour. In this case, the 'flexible' accounting arisen due to the ambiguous definition of extraordinary items.

Turncularly, during a period of low operating earnings, management may have the incentive to transactions such as losses from sales of assets or other expenses as extraordinary to operating earnings to the desired level. In contrast, according to Craig and Walsh and Choo and Peter (1998), during a period of high operating earnings, management may Lnusual gains as extraordinary to lower the operating earnings again to the desired level. 985) argues that managers may also choose to smooth reported earnings in order to maximise ses. This would be likely to occur when the managers' bonus schemes have upper and nds. Furthermore, managers may also smooth income to minimise their tax exposure bonuses (Choo and Peter, 1998).

The sest the occurrence of income smoothing which also reduces the volatility of reported earnings, I used by Choo and Peter (1998) is adopted. Profit and volatility of earnings (which is by the coefficient of variation) before and after extraordinary items are compared. Therefore, coth hypothesis, in alternative form, is:

$\mathrm{H}_{2}$ : Companies use EI to smooth income and as a result there is a significant difference in profit and volatility of earnings before and after EI.

\section{Alvothesis 3}

Managers tend to decrease the volatility of reported earnings so that their performance appears sener than what it should be. Their actions to smooth income using the classificatory choice of arraordinary items have resulted in misleading accounting numbers, particularly the reported antual earnings in the financial statements. It is widely argued that as a result of this, investors bo not get the true picture of a firm's position and performance during the particular accounting period. This is because the investors tend to concentrate on net profit after tax and pay little or no 
attention to extraordinary items although the latter form part of the enterprise's performance for the period (Choo and Peter, 1998). To empirically test whether the investors or the market ignore the existence of extraordinary items, or take into consideration the value of extraordinary items when valuing firms, the following hypothesis has been developed.

$\mathrm{H}_{3}$ : The investors take into consideration the extraordinary items reported in financial statements when valuing a firm's value.

\section{RESEARCH METHOD}

\subsection{Sample Selection}

Generally, this study was conducted on companies listed in the main board of the Kuala Lumpur Stock Exchange. The population comprised of all companies listed on the main board existing in 1999. To examine the impact of the adoption of the new standards on extraordinary items, manipulation of extraordinary items to smooth income, and investors' perception towards extraordinary items when making valuation, financial statements for six accounting periods were used. Since the new standard was made effective on 1st January 1997, this study examined the reporting of extraordinary items in the financial statements during the period of three years before and three years after the date. Specifically, the period under study was from the year 1994 to 1999 . According to Copeland (1968) a four-to-six year time horizon is adequate to reduce classification error.

This study excluded all companies that are classified under the finance sector of the Kual Lumpur Stock Exchange because of their unique features and business activities. Apart from this companies that had been de-listed during the studied period were also excluded. Companies th started to be listed later than the year 1994 had not been included in the population as well. Thi was to ensure that the sample selected from the population comprised public listed companie that existed throughout the period understudy.

The Annual Corporate Handbook (Malaysia), the published annual reports and annual report available from the World Wide Web at http://www.klse.com.my and http://www.klse-ris.com.m were assessed for data collection. Information gathered from both, the Annual Corporate Handboc (Malaysia) and the KLSE websites was used to identify companies listed on the main board of t Kuala Lumpur Stock Exchange from 1994 to 1999, which disclosed extraordinary items in the annual reports.

Consistent with the 'incidental' sampling method used by Craig and Walsh (1989), Demsey al. (1993), Beattie et al. (1994), Choo and Peter (1998) and Abdullah and Ku Ismail (2000), on 
met specified criteria were included in the sample. For this purpose, only companies anclisclosed at least once extraordinary items within the time frame, were included in the = lin addition to this, the sample did not include: (a) companies with missing data, (b) companies nat aported extraordinary items or with immaterial extraordinary items (less than RM1000) es that were listed after 1 January 1994 and (d) companies that had been de-listed period under study (during the period starting 1 January 1994 to 31 December 1999).

- final sample used in the research conducted by Craig and Walsh (1991) was 84, Dempsey 993) obtained a final sample of 248 firms, 163 firms in Beattie et al.'s (1994) study and study by Abdullah and $\mathrm{Ku}$ Ismail (2000). Table 1 shows the results of the incidental conducted. From the population of 474 companies, only 226 companies remained as the le, after considering the criteria discussed before.

Table 1

\section{The Sample Selection}

\begin{tabular}{|l|r|}
\hline Population (1999) & 474 \\
Exclude & 62 \\
Finance Sector & 127 \\
De-listed (after 1 Jan 1994) or & \\
Listed before 1 Jan 1994) & 52 \\
Immaterial or No Extraordinary items & 7 \\
Missing data & 226 \\
\hline Final Sample & \\
\hline
\end{tabular}

- stratistical Analysis

As mentioned earlier, the first hypothesis focuses on the descriptive part of the reported ardinary items included in the financial statements of Malaysian listed companies. For this e, the data has been divided into two periods, as follows: (a) from the year 1994 to 1996 , ly the period 'before the adoption'; and (b) from the year 1997 to 1999 , namely the period ter the adoption'. This hypothesis tried to detect any changes in the number of incidence of the morted extraordinary items during the two periods. To test the hypothesis, a two tailed t-test was maducted on the reported of extraordinary gains and losses for the two periods.

The second hypothesis is associated with income smoothing. To see whether management used the extraordinary items disclosure as an instrument to smooth income, two types of statistical 
tests were performed. The tests were similar to the ones used by Lynn and McGuinness (1995) Choo and Peter (1998) and Abdullah and Ku Ismail (2000). Firstly, a two-tailed paired t-test was conducted on the difference between profit before and after extraordinary items to see whether there was a statistically significant difference between profit before and after extraordinary items Secondly, the coefficient of variation (CV) for earnings before and after extraordinary items was compared across six years of available earnings data for the sample companies. This measure which is the ratio of standard deviation of earnings to mean earnings, captures the volatility earnings for a given mean ringgit amount of earnings. If $\mathrm{CV}$ of earnings after extraordinary adjustment: is significantly lower than CV of earnings before extraordinary items, it implies that extraordinary items are used to facilitate income smoothing. The one-tail test on different coefficient of variation (CV) for earnings before and after extraordinary items was also conducted.

The third hypothesis is concerned with the question of whether the market or investors hav taken into account the reported extraordinary items when valuing a firm. For this hypothesis, multivariate linear regression was conducted using the modified income statement model of marke value predictions developed earlier, which was as follows:

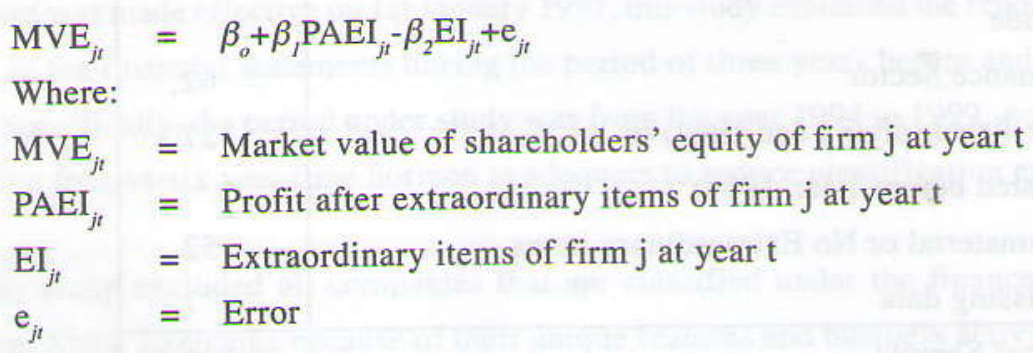

The regression was conducted separately for each year under study. If $\beta_{1}$ is significant, it impli that the investors perceive a firm's profit after extraordinary items when valuing the firm. On other hand, if $\beta_{2}$ is significant, it implies that investors take into consideration the value extraordinary items when valuing firms.

Since extraordinary items have both positive and negative values, which refer to extraordina gains and extraordinary losses respectively, another regression equation was developed to whether a different sign or direction of extraordinary items had an effect on the market value shareholders equity. A new variable was added to the original basic model used in this stu which was the dummy variable for the direction of extraordinary items. If the reported extraordin items were positive, the value for this dummy variable was 1 . On the other hand, if the extraordin items were negative, the given value for the dummy variable was 0 . The new equation is follows: 


$$
=\beta_{O}+\beta_{1} \mathrm{PAEI}_{j t}+\beta_{2} \mathrm{EI}_{j t}+\beta_{3} \mathrm{DUMMY}_{j t}+\mathrm{e}_{j t}
$$

$=$ Market value of shareholders' equity in firm $\mathrm{j}$ at year $\mathrm{t}$,

$=$ Profit after extraordinary items of firm $\mathrm{j}$ at year $\mathrm{t}$,

$=$ Extraordinary items of firm $\mathrm{j}$ at year $\mathrm{t}$,

$=$ Direction of extraordinary items of firm $\mathrm{j}$ at year $\mathrm{t}$

Ficient of the dummy variable, which is $\beta_{3}$ is significant, this implies that the direction items had some effect to the value of firms' equity. On the other hand, if the value is not significant, this would indicate that investors did not take into account the extraordinary items. In other words, it did not matter to them whether the extraordinary gains or losses.

wesen, we could foresee one potential econometric problem when using the above model as a previous researchers such as in Landsman (1986), Harris and Ohlson (1987), Barth (1991), 1991), Gopalakrishnan and Sugrue (1993), McCarthy and Schneider (1995), Jennings $996)$ and Ibrahim et al. (1999). These problems relate to the procedure for the estimation arameters of a population regression line provided by the ordinary least squares (OLS) The most common econometric problem when estimating valuation models is the problem cedastic disturbance, which arises from the fact that, large (small) companies tend to large (small) disturbances. If heteroscedasticity is present, then the standard errors are ed, resulting in overstated t-statistics. To overcome this problem, White tests are performed fiust the results. White heteroscedasticity adjusted regression equations were produced in act to each multivariate linear regression performed earlier.

\section{RESULTS}

The sample obtained during the study revealed that the total number of extraordinary items su during the period 1994 to 1999 by companies listed on the main board of Kuala Lumpur Exchange was 580. Table 2 shows that companies classified under different industries, nequal proportions, reported these items. According to the table, the property sector had ghest number of reported extraordinary items, with 47 extraordinary losses and 64 extraordinary totaling 111 extraordinary items.

On the other hand, the sector with the lowest number of reported extraordinary items was the sector. This sector reported only 2 cases of extraordinary losses and an extraordinary gain $\mathrm{g}$ the six-year period. Extraordinary items are classified as either positive or negative. Positive 
cases refer to gains or additions to profits while negative cases refer to losses or deductions from profits. Table 2 shows that out of 580 extraordinary items reported during the six-year period, only 226 items or $38.97 \%$ were extraordinary losses. On the other hand, extraordinary gains reported during the period amounted to 354 , which was $61.03 \%$ of the total extraordinary items. This shows that the number of extraordinary gains reported was greater compared to extraordinary losses. This is in contrast with the findings in a research done by Dempsey et al. (1993), which revealed that managers showed a propensity to report losses as extraordinary items and gains a part of ordinary income.

There were only 266 companies that reported extraordinary items from 1994 to 1999 . From the amount, 73 companies reported extraordinary items once, 91 companies reported the item twice and 86 companies reported them three times during the period. From the year 1994 to 1999 only 13 companies reported extraordinary items four times, while 3 companies reported the item 5 times. None of the companies reported extraordinary items for six consecutive years.

Table 2

Reported Extraordinary Items by Industries

\begin{tabular}{|l|cc|c|}
\hline \multirow{2}{*}{\multicolumn{1}{|c|}{ INDUSTRY }} & \multicolumn{2}{c|}{ Direction } & \multirow{2}{*}{ Total } \\
\cline { 2 - 3 } & Loss & Gain & 54 \\
\hline Building Material & 27 & 27 & 47 \\
Construction & 22 & 25 & 46 \\
Consumer Product & 17 & 29 & 22 \\
Food, Beverages \& Tobacco & 9 & 13 & 15 \\
Gaming & 6 & 9 & 6 \\
Hotels & 3 & 3 & 66 \\
Industrial Products & 32 & 34 & 34 \\
Investment Holding & 9 & 25 & 19 \\
Mining & 3 & 16 & 73 \\
Plantation & 14 & 59 & 111 \\
Property & 47 & 64 & 9 \\
Publishing \& Media & 5 & 4 & 3 \\
Retail & 2 & 1 & 12 \\
Securities \& Investment & 226 & 6 & 53 \\
Trading \& Services & 3 & 32 & 10 \\
Transportation & 21 & 7 & 58 \\
\hline Total & 34 & \\
\hline
\end{tabular}


wally, the number of reported extraordinary items increased from the year 1994 to 1995 . = in decreased from 1995 to 1999. This is shown in Table 3. In 1994, there were 79

losses and 119 extraordinary gains, which made up a total of 198 . The numbers 74 and increased to 127, respectively for the year 1995. In 1996, there were fewer extraordinary items where both numbers of extraordinary losses and gains decreased 4 s3 correspondingly. The year 1997 evidenced a major drop in the number of reported inary items. Only 15 extraordinary losses and 23 extraordinary gains were reported. This ved by 3 cases of extraordinary losses and 2 cases of extraordinary gains reported in extraordinary item case was reported in the year 1999.

number of reported extraordinary items from 1994 till 1996 was 537, while the total the extraordinary items reported from 1997 to 1999 was 43 . Therefore, it is obvious number of reported extraordinary items during the period before the adoption of the rd was greater than the amount of extraordinary items reported during the period after of the new standard. This means that hypothesis 1 is accepted since there is a significant e between the incidence of extraordinary items during the period before and after the of the new standards among Malaysian listed companies.

Table 3

Reported Extraordinary Items Between Periods

\begin{tabular}{|c|c|c|c|c|c|c|c|}
\hline \multirow[b]{2}{*}{ Feriod } & \multirow[b]{2}{*}{ Year } & \multicolumn{4}{|c|}{ Direction } & \multirow[b]{2}{*}{ Total } & \multirow[b]{2}{*}{$\begin{array}{c}\mathrm{t} \text {-value } \\
\text { (p-value) }\end{array}$} \\
\hline & & Loss & $\begin{array}{c}\text { t-value } \\
\text { (p-value) }\end{array}$ & Gain & $\begin{array}{c}\mathrm{t} \text {-value } \\
\text { (p-value) }\end{array}$ & & \\
\hline \multirow{4}{*}{ Ats Adoption } & 1994 & 79 & & 119 & & 198 & \\
\hline & 1995 & 74 & & 127 & & 201 & \\
\hline & 1996 & 55 & 7.340 & 83 & 6.579 & 138 & 6.939 \\
\hline & 1997 & 15 & $(0.00)$ & 23 & $(0.00)$ & 38 & $(0.00)$ \\
\hline \multirow[t]{2}{*}{ Anser Adoption } & 1998 & 3 & & 2 & & 5 & \\
\hline & 1999 & 0 & & 0 & & 0 & \\
\hline
\end{tabular}

These findings are consistent with the comments made by Choo and Peter (1998), which claimed te narrowed definition of extraordinary items has abolished the items from the firm's income ent. This can be seen clearly by the significant drop in the number of extraordinary items wifer the period of adoption to the extent that it became nil in 1999. 


\section{EXTRAORDINARY ITEMS AND INCOME SMOOTHING}

For the second hypothesis, two types of tests were conducted to identify whether extraordinar items classificatory choices were being used in smoothing a firm's annual earnings. In the firs test of Hypothesis 2, income smoothing was posited to occur when a statistically significant differenc was observed between profit before and after extraordinary items at the 5\% level of significance Since the sample size for the year 1998 and 1999 was inadequate (below 30), the tests were conducte for 1994 to 1997 only. The results for the tests are shown in Table 4.

Table 4

Two-Tail Paired T-test Result on Profit Before and After Extraordinary Items

\begin{tabular}{|ccccrccc}
\hline Variable & Year & Mean & \multicolumn{1}{c}{$N$} & \multicolumn{1}{c}{ S.D } & \multicolumn{1}{c}{$t$} & Df & $p$-value \\
\hline PAEI & 1994 & 62128.47 & 198 & 131631.27 & 4.806 & 197 & 0.000 \\
PBEI & 1994 & 48231.41 & 198 & 121943.35 & & & \\
PAEI & 1995 & 64544.98 & 201 & 96466.44 & 4.184 & 200 & 0.000 \\
PBEI & 1995 & 51053.90 & 201 & 78228.72 & & & \\
PAEI & 1996 & 74104.81 & 138 & 165693.72 & 2.474 & 137 & 0.015 \\
PBEI & 1996 & 51971.64 & 138 & 117531.94 & & & \\
PAEI & 1997 & 29708.71 & 38 & 141778.57 & -0.474 & 37 & $0.638^{* *}$ \\
PBEI & 1997 & 36805.34 & 38 & 67596.29 & & & \\
\hline
\end{tabular}

"After the adoption of the new accounting standard on extraordinary items

The table shows that, the two-tail paired t-tests on the difference between profit before after extraordinary items for 1994, 1995 and 1996 was significant at 5\% level. In all cases, means of PAEI were higher than the means of PBEI for the year before the adoption of the standard. This implies that extraordinary items were being used as a tool to smooth income dur the period before the adoption of the new standards. However, the results of the t-test for period after the adoption of the new standards contradicted with the results for the period bef the adoption. The $t$-value was -0.474 for the year 1997 , which was insignificant at $5 \%$ level. T was contrary to the prediction of income smoothing by management. Thus, in general manageme did not use extraordinary items disclosure as an instrument to smooth income during the peri after the adoption of the new standards.

The second test for this hypothesis compared the coefficient of variation (CV) for earni before and after extraordinary items across five years available earnings data for the sample compar As discussed earlier, the $\mathrm{CV}$ measures the volatility of earnings for a given mean ringgit amo- 
If $\mathrm{CV}$ of earnings after the extraordinary adjustments is significantly lower than $\mathrm{CV}$ efore extraordinary items, it implies that extraordinary items are used to facilitate his purpose, the 6-year period was divided into two, period before and period after of the new standards. The results are shown in Table 5. For the period before the new standards, the mean CV of earnings after the extraordinary adjustments was was lower than the mean CV of earnings before extraordinary items (2.1073). This hat extraordinary items were used to facilitate earnings. However, this result was at $5 \%$ level.

Table 5

One-Tail T-test Result of CV Before and After Extraordinary Items

\begin{tabular}{|crrccc|}
\hline Nuriables & Year & Mean & S.D & $T$ & $p$-value \\
\hline CVPBEI & $1994-96$ & 2.1073 & 0.5156 & 1.25 & 0.338 \\
CVPAEI & $1994-96$ & 1.9497 & 0.3985 & & \\
CVPBEI & $1997-99$ & 1.6015 & 0.3324 & -1.463 & 0.382 \\
CVPAEI & $1997-99$ & 3.3455 & 2.0178 & & \\
\hline
\end{tabular}

The results were different for the period after the adoption of the new standards. The mean CV igs after the extraordinary adjustments (3.3455) was higher than the mean $\mathrm{CV}$ of earnings extraordinary items (1.6015), indicating that extraordinary items were not being used to earnings. Similarly, this result is insignificant at $5 \%$ level. From both tests, there is that extraordinary items were being used as an instrument of income smoothing during iod before the adoption of the new standards. Thus, hypothesis 2 that states that companies rdinary items to smooth income is accepted since there is a significant difference in and volatility of earnings before and after extraordinary items.

\section{MIIRAORDINARY ITEMS AND MARKET VALUE}

The third hypothesis concerns the question of whether market perceived the existence of finary items in the financial statements when valuing a firm. To answer the third hypothesis, models had been used and the results are illustrated in Tables 6 to Table 8 .

\section{Basic Model}

Empirical analysis for the third hypothesis was based on the basic market value and net income which was introduced by Barth et al. (1992). This income statement model was modified 
for the purpose of this study by decomposing net income into profit after extraordinary item (PAEI) and extraordinary items (EI). The model tested in this study was:

$$
\mathrm{MVE}_{\mathrm{jt}}=\beta_{0}+\beta_{1} \mathrm{PAEI}_{\mathrm{jt}}+\beta_{2} \mathrm{EI}_{\mathrm{jt}}+\mathrm{e}_{\mathrm{jt}}
$$

Table 6

Market Value Predictions (The Basic Model)

\begin{tabular}{|c|c|c|c|c|c|}
\hline Predicted Sign & $\begin{array}{c}\beta_{0} \\
?\end{array}$ & $\begin{array}{l}\beta_{1} \\
+\end{array}$ & $\beta_{2}$ & $\mathrm{R}^{2}$ & $\mathrm{~N}$ \\
\hline $\begin{array}{l}1994 \\
\text { OLS-t }\end{array}$ & $\begin{array}{l}326874^{* * * *} \\
4.811\end{array}$ & $\begin{array}{l}17.074^{* * *} \\
34.123\end{array}$ & $\begin{array}{l}-13.817^{* * *} \\
-8.535\end{array}$ & 0.859 & 198 \\
\hline $\begin{array}{l}1995 \\
\text { OLS-t }\end{array}$ & $\begin{array}{l}79109 \\
0.989\end{array}$ & $\begin{array}{l}20.176^{* * *} \\
23.506\end{array}$ & $\begin{array}{l}-21.320^{* * *} \\
-11.802\end{array}$ & 0.740 & 201 \\
\hline $\begin{array}{l}1996 \\
\text { OLS-t }\end{array}$ & $\begin{array}{l}555385^{* * *} \\
4.214\end{array}$ & $\begin{array}{l}14.632^{* * *} \\
14.307\end{array}$ & $\begin{array}{l}-14.363^{* * *} \\
-8.907\end{array}$ & 0.606 & 138 \\
\hline $\begin{array}{l}1997 \\
\text { OLS-t }\end{array}$ & $\begin{array}{l}392045^{* * *} \\
3.791\end{array}$ & $\begin{array}{l}13.175^{* * *} \\
8.682\end{array}$ & $\begin{array}{l}-17.043^{* * *} \\
-7.315\end{array}$ & 0.691 & 38 \\
\hline
\end{tabular}

Notes: The table indicates significance at $1 \%\left({ }^{* * *}\right)$

Model (Basic): $M V E_{j t}=\beta_{0}+\beta_{l} P A E I_{j}+\beta 2 E I_{j}+e_{j t}$

The results of this analysis are reported in Table 6 . The table shows that the coefficients PAEI were significant at $1 \%$ confidence level. This result implies that the investor considered PAEI in valuing the firm's value during the four-year period. The coefficients also showed PAEI was positively related to the market value of equity. For extraordinary items, the coefficie of extraordinary items for the four years were significant at $1 \%$ confidence level. This imp that the investor considered extraordinary items in determining the value of the firms. The coefficic also showed that the value of the firms has negative relation with extraordinary items.

\section{Direction of Extraordinary Items}

To overcome the issue of whether extraordinary items direction which was positive and nega had effects on the market value of shareholders equity, a new variable was added to the orig model used in this study. The basic model had been extended to include a dummy variable. dummy variable stood for the direction of extraordinary items, which were divided into posit (extraordinary gains) and negative (extraordinary losses). Extraordinary gains possessed a v of 1 , while extraordinary losses possessed a value of 0 . The new extended model is as follow

$$
\text { MVE }_{j t}=\beta_{0}+\beta_{1} \text { PAEIt }_{j}+\beta_{2} E_{j t}+\beta_{3} \text { DUMMY }_{j t}+e_{j t}
$$


variable included in this new model could identify whether the direction of tems affected the investors when valuing a company. If the coefficient for the dummy, cant, then this implied that the direction of extraordinary items was important for when valuing the company. The results generated using this model are shown in

showed that the coefficients were not significant at $5 \%$ confidence level during the This implied that the investor ignored the sign of extraordinary items in valuing ghout the studied period. In other words, the direction of extraordinary items was to the investors. On the other hand, for extraordinary items, the coefficients $\left(\beta_{2}\right)$ cant at $1 \%$ confidence level. This implied that the investor considered extraordinary In determining the value of the firms regardless of the direction of the extraordinary

Table 7

Market Value Predictions (Dummy Variable Included)

\begin{tabular}{|c|c|c|c|c|c|c|}
\hline Theticted Sign & $\begin{array}{c}\beta_{0} \\
?\end{array}$ & $\begin{array}{l}\beta_{1} \\
+\end{array}$ & $\begin{array}{c}\beta_{2} \\
-\end{array}$ & $\begin{array}{c}\beta_{3} \\
?\end{array}$ & $\mathrm{R}^{2}$ & $\mathrm{~N}$ \\
\hline 1394 & $304250^{* * *}$ & $17.057^{* * *}$ & $-14.000^{* * *}$ & 43656 & 0.859 & 198 \\
\hline OCS-t & 3.111 & 33.817 & -8.146 & 0.322 & & \\
\hline 1995 & -22667 & $20.167^{* * *}$ & $-21.897^{* * *}$ & 174324 & 0.742 & 201 \\
\hline OLS-t & -0.195 & 23.582 & -11.731 & 1.208 & & \\
\hline 1996 & $583459^{* * *}$ & $14.653^{* * *}$ & $-14.315^{* 2 *}$ & -50978 & 0.606 & 138 \\
\hline OLS-t & 3.012 & 14.203 & -8.749 & -0.198 & & \\
\hline 1997 & $295606^{* *}$ & $12.919^{* * *}$ & $-17.050^{* * *}$ & 171836 & 0.698 & 38 \\
\hline OLS- $t$ & 1.983 & 8.346 & -7.298 & 0.901 & & \\
\hline
\end{tabular}

Sunes: The table indicates significance at $1 \%(* * *)$ and $5 \%(* *)$ levels.

Whistel (Extended): $M V E_{j t}=\beta_{0}+\beta_{l} P A E I_{j t}+\beta_{2} E I_{j t}+\beta_{3} D U M M Y_{j t}+e_{j t}$

\section{cedasticity Issue}

Dne common econometric problem that often arises when conducting a cross-sectional analysis a the beteroscedasticity problem. According to Ibrahim et al. (2001), one of the major econometric mablems when estimating cross-sectional valuation models is the problem of heteroscedastic fisarbances that appears from the fact that large (small) firms tend to produce large (small) 
If heteroscedasticity is present, then the usual OLS estimators, although unbiased, no longe exhibit minimum variance among all linear unbiased estimators (Gujarati, 1995). In short, the are no longer the best linear unbiased estimator. To overcome the heteroscedasticity problem, procedure established by White (1980) was carried out. This procedure, which is known as t heteroscedasticity-consistent covariance matrix estimators (HCCME), produces consistent estimat: of the variances and covariances of OLS estimators even if there is heteroscedasticity problem

Table 8 lists the summary statistics from the basic regression models that were based on White heteroscedasticity adjusted standard errors. The table shows different t-values, compared to t ordinary least squares results reported earlier. However, the overall results were consistent wi the previous results, which the coefficients of extraordinary items for the four years were signific at $1 \%$ confidence level. This implies that the investor considered extraordinary items in determini the value of the firms. Likewise, the coefficient had negative values suggesting that the grea the amount of extraordinary items, the lower the value of the firms regardless the direction of extraordinary items.

Table 8

Market Value Predictions - The Basic Model

(White's Heteroscedasticity Adjusted Standard Error's)

\begin{tabular}{|c|c|c|c|c|c|}
\hline Predicted Sign & $\begin{array}{c}\beta_{0} \\
?\end{array}$ & $\begin{array}{l}\beta_{1} \\
+\end{array}$ & $\beta_{2}$ & $\mathrm{R}^{2}$ & $\mathrm{~N}$ \\
\hline 1994 & $326874.100^{* * *}$ & $17.074^{* * *}$ & $-13.817^{* * *}$ & 0.859 & 198 \\
\hline White-t & 5.933 & 12.919 & -6.230 & & \\
\hline 1995 & 79108.700 & $20.176^{* * *}$ & $-21.320^{* * *}$ & 0.740 & 201 \\
\hline White-t & 0.860 & 6.902 & -4.916 & & \\
\hline 1996 & $555384.800^{* *}$ & $14.632^{* * *}$ & $-14.363^{* * *}$ & 0.606 & 138 \\
\hline White-t & 1.762 & 2.744 & -2.415 & & \\
\hline 1997 & $392044.600^{\text {**** }}$ & $13.175^{\text {**** }}$ & $-17.043^{* * *}$ & 0.691 & 38 \\
\hline White-t & 3.931 & 7.817 & -6.645 & & \\
\hline
\end{tabular}

Notes: The table indicates significance at $1 \%\left({ }^{* * *}\right)$ and $\left.5 \%(")^{*}\right)$ levels.

Model: $M V E_{j t}=\beta_{0}+\beta_{l} P A E I_{j}+\beta_{2} E I_{j}+e_{j t}$

\section{SUMMARY AND CONCLUSIONS}

The purpose of this research was to increase the general understanding on the issues regard the reporting of extraordinary items. Specifically, the goal of this study was to determine whet 
of new standards on extraordinary items had effects on the incidence of extraordinary ed in the financial statements of Malaysian listed companies, to examine whether y items was being used as a tool in income smoothing and to identify whether investors sideration the reported extraordinary items when valuing firms.

gs reveal that there is an obvious decrease in the number of incidence of extraordinary he adoption of the new standards. The narrowed definition of extraordinary items has use of these items as well as reduced the opportunity of using extraordinary items choices to smooth income. The evidence shows that extraordinary items are being strument to smooth income during the period before the adoption of the new standards. hand, the statistical tests also reveal that extraordinary items are not being used in thing during the succeeding period. This implies that the standards setting bodies in (ASB) has taken a proper action in reducing the creative and manipulative accounting nthe country. After the adoption of the new standard, it was no more possible for the tement preparers to use extraordinary items classificatory choices to smooth firm's e. By limiting the definition of extraordinary items, the new revised standard drives g preparers to produce more useful and reliable financial statements. As a consequence, statements users especially the investors have more confidence to rely on the accounting when making economic decisions.

Ectheless, although it is proved that the narrowed definition of extraordinary items curbs manipulating the reported income, the statistical evidence gathered from multivariate lemonstrate that extraordinary items are value-relevance for investors in valuing a This implies that investors took into account the extraordinary items even though it $d$ 'below the line'. In other words, the market will not be misled by the firms' smoothed e they also consider the firm's extraordinary items when making decisions. 


\section{REFERENCES}

Abdullah, S.N., \& Ku Ismail, K.N.I. (2000, February). The reporting of extraordinary items among Malaysian listed companies: Evidence prior to the adoption of IAS 8 (Revised), Akauntan Nasional Malaysia, pp.28-35.

Ball, R., and Brown, P. (1968). Empirical evaluation of accounting numbers. Journal of Accountin Research, pp 159-178.

Barnea, A., Ronen, J., \& Sadan, S., (1976). Classificatory smoothing of income with extraordinar items, The Accounting Review, 110-122.

Barth, M.E., (1991). Relative measurement errors among alternative pension asset and liabil measures, The Accounting Review, Vol. 66, No. 3, pp 443-463.

Barth, M.E., Beaver, W.H., and Landsman, W.R., (1992). The market valuation implication of periodic pension cost components, Journal of Accounting and Economics, Vol. 15, pp 27-62.

Beattie, V., Brown, S., Ewers, D., John, B., Manson, S., Thomas, D., \& Turner, M. (199Extraordinary items and income smoothing: A positive accounting approach, Journal of Busin Finance and Accounting, 21 (6), 791-811.

Choo, T.M., and Peter, L.L.N. (1998). Accounting for extraordinary items in Singapore: Empir findings and international implications, Journal of International Accounting, Auditing \& Taxat Vol.7 (2), pp. 215-232

Copeland, R.M. (1968). Income smoothing, Journal of Accounting Research (Suppleme pp.101-116.

Cornell B., and Landsman, W.R. (1989). Security prices responses to quarterly earnings announcer and analysts' forecast errors. Journal of Accounting Research, 64, pp 680-692.

Craig, R., and Walsh, P. (1989), Adjustments for 'extraordinary items' in smoothing repo profits of listed Australian companies: Some empirical evidence, Journal of Business Fin and Accounting, pp.229-245.

Dempsey, S.J., Hunt III, H.G., and Schroeder, N.W. (1993). Earnings management and corp ownership structure: An examination of extraordinary items reporting, Journal of Business Fin and Accounting, Vol. 20(4), pp.479-500. 
n. V., and Sugrue, T.F. (1993), An empirical investigation of stock market valuation projected pension liabilities, Journal of Business Finance \& Accounting,

DN., (1995), Basic Econometrics, Third Edition, McGraw-Hill Inc, New York.

ts and Ohlson, J.A. (1987). Accounting disclosure and the market's valuation of oil and The Accounting Review, Vol. 62, No. 4, pp 651-670.

1985). The impact of bonus scheme on the selection of accounting principles, Journal g and Economics.

- M. K., Mcleay, and S., Neal, D., (1999), Market value, book value and goodwill, British Association Conference, Glasgow University, United Kingdom.

M.K., Mohd. Said, M., Abd. Latif, R., and Abd. Shukur, Z. (2001), Value-relevance of $\mathrm{g}$ numbers: An empirical investigation of purchased goodwill, Conference on Business, of Hawaii, United States.

Accounting Standards Committee (1992). Net profit or loss for the period, fundamental and changes in accounting policies, International Accounting Standards (IAS) 8, London,

Es, R., Robinson, J., Thompson II, R.B., and Duvall, L. (1996), The relation between accounting numbers and equity values, Journal of Business Finance \& Accounting, pp 513-533.

an, W., (1986). An empirical investigation of pension fund property rights, The Accounting Vol. 61, No. 4, pp 662-691.

E.EJ., and Unal,H. (1990). Modelling structural and temporal variation in the market's valuation ing firms, Journal of Finance, Vol. XLV, No 1, pp 113-136.

M., and McGuinness, P. (1995). The incidence, nature and impact of extraordinary items - earnings: An exploratory study for Hong Kong, International Journal of Accounting, pp.62-81 WeCarthy, M.G., and Schneider, D.K., (1995). Market perception of goodwill: Some empirical widence, Accounting and Business Research, pp 69-81. 
Naser, K.H. (1993). Creative Financial Accounting: Its Nature and Use, Prentice Hall, UK.

Shevlin, T. (1991, January). The valuation of R \& D firms with R \& D limited partnerships, $T$ Accounting Review, Vol. 66, No. 1, pp 1-21.

White, H., (1980). A heteroscedasticity-Consistent Covariance Matrix and a Direct Test Heteroscedasticity, Econometrica, pp 817-838. 